\title{
The mediating role of process and product innovation in the relationship between environmental management accounting and firm's financial performance
}

\begin{abstract}
This study aims to investigate the mediating role of product and process innovation in the relationship between environmental management accounting (EMA) and firm's financial performance in Iranian companies. The paper adopted the structural equation modelling (SEM) approach to test the hypotheses. The findings are based on 118 Iranian manufacturing and consumer product firms in 2014. The findings reveal that the link between environmental management accounting and financial performance is a partial mediated relationship. Positive effect of environmental management accounting on financial performance is due to the positive effect environmental management accounting has on both product and process innovation on one hand and positive affect that innovation has on financial performance on the other. These findings suggest a role for environmental management accounting in indirectly promoting firm performance through enhancing innovation.
\end{abstract}

Keyword: Environmental management accounting; EMA; Product innovation; Process innovation; Firm performance; Iran 